\title{
Evaluation of animal-related injuries from the perspective of 7423 cases admitted to Emergency Department
}

\section{Acill Servise Başvuran 7423 Olgu Üzerinden Hayvan-İlişkili Yaralanmaların İncelenmesi}

\author{
Erdal Demirtaş ${ }^{1}$, Sertaç Güler ${ }^{2}$, Hikmet Duymaz ${ }^{2}$, Murat Soyudurư ${ }^{3}$, Sami Kınıklı , \\ Figen Coşkun ${ }^{5}$

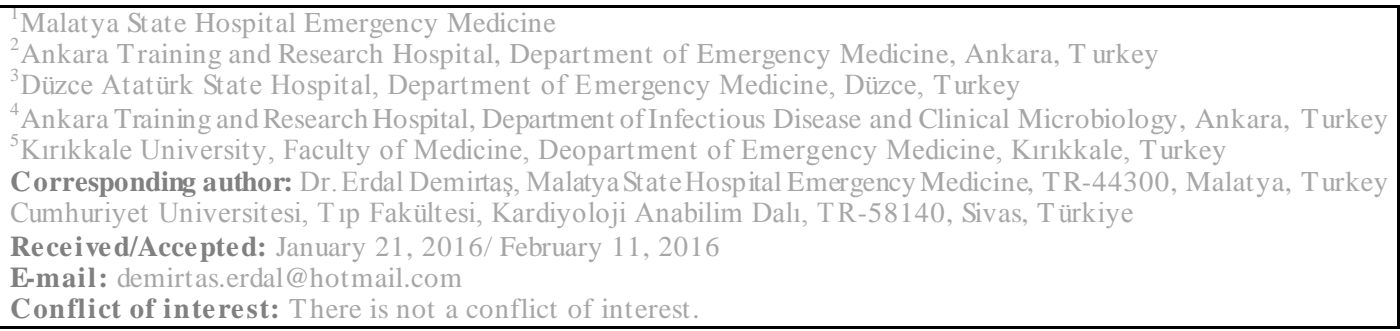

\section{SUMMARY}

Objective: Animal-related injuries are major issues of public health in all over the world and in our country as well. These animal-related injuries may result in serious complications like infections. In our study we aimed to investigate the sociodemographic characteristics, the features of contact related to animal bites or exposure to rabies risk, prophylactic treatment strategies and appropriateness of post-exposure prophylaxis in patients with animal-related injuries.

Method: This study was retrospectively designed by collecting data of the patients with animal related and bite wound injuries admitted to the emergency department of Ankara Training and Research Hospital during the years of 2010 and 2011. The data was analysed by using SPSS 11.5 software programme.

Results: The study was consisted of 7423 patients. Animal related injuries were mostly seen in male patients $(66.4 \%)$ and the mean age of the patients was $31 \pm 18$. These injuries were mostly during spring and summer. In $80.8 \%$ of the patients the injuries were due to animal bites. Of the 7423 patients; $69.8 \%$ were injured by dogs, $27.5 \%$ by cats and $0.2 \%$ by wild animals. The location of the bite wounds were in the upper extremities in $51.6 \%$, lower extremities in $39.7 \%$, head and neck in $4.6 \%$, chest in $2.4 \%$ and back in $1.7 \%$ of the patients. Lacerations were the most common type of injury. Of the patients $43.6 \%$ received $2+1+1$ rabies vaccination schedule, $7.1 \%$ received $2+1+1$ rabies vaccination schedule and immunoglobulin, $12.9 \%$ received 5 dosage vaccination schedule. Of the patients $34.4 \%$ followed up for 10 days without any rabies prophylaxis.

Conclusions: According to the results of our study; most of the animal related injuries are caused by dogs. Dogs mostly cause bite injuries whereas cats cause scatch injuries. Wounds are located generally in the extremities. Head and neck injuries are more common in pediatric group compared with other age groups. Rabies prophylaxis application strategies were changed if the dogs were owned or not and according to the existence of the lesion.

Keywords: Domestic animals, wild animals, wounds and injuries, lacerations, emergency department (MeSH Database)

ÖZET

Amaç: Hayvan-ilişkili yaralanmalar tüm dünyada olduğu gibi ülkemizde de önemli bir halk sağlığ1 sorunudur. Bu yaralanmalarda ciddi enfeksiyonlar gibi komplikasyonlar oluşabilmektedir. Çalışmamızda hayvan-ilişkili yaralanmalar nedeni ile acil servise başvuran hastalarda sosyodemografik özellikleri, kuduz riskli temas niteliklerini ve profilaksi yaklaşımlarını, temas sonrası profilaksinin uygunluğunu incelemeyi amaçladık. 
Yöntem: Bu çalş̧ma 2010-2011 yılları süresince Ankara Eğitim ve Araştırma Hastanesi acil servisine hayvan-ilişkili yaralanma nedeni ile başvuran 7423 hastanın dosya kayıtlarının retrospektif olarak değerlendirilmesiyle yapılımıstır. Çalışmada elde edilen veriler SPSS 11.5 paket programında değerlendirilmiştir.

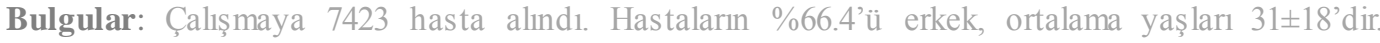
Hayvan-ilişkili yaralanmaların bahar ve yaz aylarında arttığı, bireylerin \%80.8'inin isırılma yolu ile temasa uğradığ 1 belirlendi. Hastaların \%69.8'inde etken köpekler, \%27.5'inde kediler, $\% 0.2$ 'sinde ise vahşi hayvanlard1. Hastaların $\% 51.6$ 's1 üst ekstremite, \%39.7'si alt ekstremite, \%4.6's baş ve boyun, \%2.4'ü göğüs ve \%1.7'si sirt bölgesinden yaralanmışt1. En çok izlenen yaralanma tipi laserasyondu. Hastaların \%43.6'sına 2+1+1 kuduz aşı1s şemas1 uygulandığı, \%7.1'ine $2+1+1$ kuduz aşısı ve immunglobülin uygulandı̆̆1, \%12.9'una 5 doz aş1 şeması uygulandığı belirlendi. Hastaların \%34.4'ünün ise kuduz profilaksisi uygulanmadan 10 gün izleme alındığ 1 tespit edildi.

Sonuç: Hayvan-ilișkili yaralanmalara en sık köpekler neden olmaktadır. Mekanizma köpekler için daha çok ısırma, kediler için tırmalamadır. Sıklkkla ekstremite bölgelerinde yaralanmaların oluştuğu, çocukluk yaș grubunda ise baș boyun bölgesindeki yaralanmaların diğer yaşlara göre yüksek olduğu görülmüştür. Hayvanın sahipli ve aşılı olması veya lezyonun mevcut olup olmamasına göre kuduz profilaksisi uygulamasının değişiklikler gösterdiği belirlenmiştir.

Anahtar sözcükler: Evcil hayvanlar, vahşi hayvanlar, yaralar ve yaralanmalar, laserasyonlar, acil tip (MeSH Database)

\section{INTRODUCTION}

Throughout the world, as well as Turkey, animal-related injuries (ARIs) are one of the most common hospitalization reasons in the emergency departments (EDs). There are approximately 50 million pets in the USA and every year 2-5 million biting cases are being reported. Approximately 300 thousand of these cases admitted to EDs, 10 thousand is being hospitalized and 20 lost their lives. In Turkey, a study reported 25,480 biting cases only in Ankara between 2005 and $2009^{1}$. Considering these numbers and consequences such as scarring, disfiguration, disability, infection, even death, we can easily say that ARI is a serious public health problem. Rabies prophylaxis, simply consist of preexposure and post-exposure measures. Preexposure prophylaxis is measures applied to persons in high risk of rabies, such as veterinaries, zoo keepers, laboratory technicians etc, whereas post-exposure prophylaxis are based on dressing the wound, and injection of rabies vaccine and/or rabies immunoglobulin (Ig) steps ${ }^{2}$.

In this study, we aimed to investigate the ARI cases admitted to the ER in terms of socio-demographic characteristics, injury dynamics and locations, risks for rabies, prophylactic approaches and appropriateness of the post-exposure prophylaxis.

\section{METHOD}

This is a descriptive, cross-sectional, retrospective study covering 7423 patients admitted to the ED of Ankara Training and Research Hospital during the years of 2010 and 2011 because of all ARI cases admitted to this ED are being referred to the Department of Infectious Diseases and Clinical Microbiology of the same hospital, as it is the only rabies center in the province. Due to Ankara training and research hospital is the biggest rabies center of Ankara region the number of cases are significantly high in this study. For all 7423 patients, standardized forms are prepared based on data collected from the ED records and the records of the Department of Infectious Diseases and Clinical Microbiology. Socio-demographic characteristics of the patient, the type of the animal, bite location, type of the lesion and prophylactic status are analyzed.

The approval of the ethics committee was taken for this study. We also took the approval of the local ethics committee. We used SPSS package program (version 11.5, SPSS Inc., Chicago, IL) for statistical analysis. Descriptive statics are expressed as follows: continuous variables as mean \pm standard deviation, and categorical variables as number (n) and percentage (\%). Categorical variables are subjected to the chi-square test. Statistical significance 
level is accepted as $\mathrm{p}<0.05$.

\section{RESULTS}

The mean age of the patients was 31.71 $(\min .=2, \quad \max .=93) .4926$ patients (66.4\%) were male and 2497 patients (33.6\%) were female. 867 patients $(11.7 \%)$ were 10 years old or younger. ED admittion has higher in summer season $(31,6 \%)$, and has at least during the winter season $(21,1 \%)$. Patients were exposed either by being bitten (5998 cases, $80.8 \%$ ) or scrabbled (1271 cases, $16.6 \%)$. The types of the attacking animal were dogs (5032 cases, $83.9 \%$ ), cats (2041 cases, $27.5 \%$ ), other domestic animals (mice, horse, monkey etc.) (191 cases, 2.6\%), and wild animals (13 cases, $0.2 \%$ ). There was a statistically significant relation between attacking animal and contact type $(\mathrm{p}<0.05)($ Table 1$)$

Table 1. The relation between the attacking animal and contact type.

\begin{tabular}{|l|l|l|l|l|l|}
\hline \multirow{2}{*}{} & \multicolumn{4}{|l|}{ Attacking animal } & \multirow{2}{*}{ Total } \\
\cline { 2 - 6 } & Dog & Cat & $\begin{array}{l}\text { Wild } \\
\text { animal }\end{array}$ & Other domestic & \\
\hline & $\mathrm{N}(\%)$ & $\mathrm{N}(\%)$ & $\mathrm{N}(\%)$ & $\mathrm{N}(\%)$ & $\mathrm{N}(\%)$ \\
\hline Biting & $5032(83.9)$ & $901(15.0)$ & $12(0.2)$ & $53(0.9)$ & $5998(100)$ \\
\hline Scrabbling & $99(8)$ & $1125(91.4)$ & $0(0.0)$ & $7(0.6)$ & $1231(100)$ \\
\hline Open wound contact & $4(66.7)$ & $0(0.0)$ & $0(0.0)$ & $2(33.3)$ & $6(100)$ \\
\hline Other & $43(22.9)$ & $15(8.0)$ & $1(0.5)$ & $129(68.6)$ & $188(100)$ \\
\hline Total & $5178(69.8)$ & $2041(69.8)$ & $13(0.2)$ & $191(2.6)$ & $7423(100)$ \\
\hline
\end{tabular}

chi-square: $6396.555 ; \mathrm{p}=0.000$.

The most common lesion type was laceration $(61.4 \%)$ (Table 2)

Table 2. Lesion types after the exposure.

\begin{tabular}{|l|l|}
\hline LESION TYPE & $\mathbf{N}(\%)$ \\
\hline Laceration & $4557(61.4)$ \\
\hline Dermabrasion-bruising-bite marks & $2243(30.2)$ \\
\hline Scratch & $555(7.5)$ \\
\hline Ecchymosis & $68(0.9)$ \\
\hline Total & $7423(100)$ \\
\hline
\end{tabular}

The contact locations of the lesions were extremities (6779 cases, 91.3\%), head and neck (339 cases, $4.6 \%$ ) and chest and neck (305 cases, $4.1 \%$ ) (Table 3).
Table 3. Contact locations of the lesions

\begin{tabular}{|l|l|}
\hline Body Part & $\boldsymbol{N}(\%)$ \\
\hline Lower extremities & $2947(39.7)$ \\
\hline Upper extremities & $3832(51.6)$ \\
\hline Head and neck & $339(4.6)$ \\
\hline Chest & $176(2.4)$ \\
\hline Back & $129(1.7)$ \\
\hline Total & $7423(100)$ \\
\hline
\end{tabular}

When the relation between attacking animal and contact location is examined, we observed that dogs are statistically significant more likely to attack to extremities, cats to upper extremities $(\mathrm{p}<0.05)$ (Table 4). 
Table 4. The relation between attacking animal and contact location.

\begin{tabular}{|c|c|c|c|c|c|}
\hline & \multicolumn{4}{|c|}{ Attadizf aninal } & \multirow{2}{*}{ Total } \\
\hline & Degt & Cat & ayd antraks & Other & \\
\hline & $N\left(B_{0}\right)$ & $\mathrm{N}(\%)$ & $\mathrm{x}(\mathrm{s})$ & $\mathrm{N}(\infty)$ & $\mathrm{x}(\mathrm{s})$ \\
\hline Lower extisuritis & $2503(08.0)$ & 235 (2.7) & $4(0.1)$ & $65(2)$. & $24)^{(066)}$ \\
\hline Opper estuention & 21911960 & $155)(41.9)$ & $9(0.3)$ & $55(2.3)$ & $3832(106)$ \\
\hline Head and nock & $188(35.5)$ & $135(99.8)$ & $0(0,6$ & $16 \times 4.7)$ & 399 (10) \\
\hline Cheut & 138 (7K. 4 ) & $22(125)$ & 000 & If(2.1) & 176 (100) \\
\hline Ausk & $\cos (83.7)$ & $1293)$ & $0(0,5)$ & $9(7.0)$ & $129(100)$ \\
\hline Tatoof & $5 I 79,60.04$ & 2041127.59 & $13 \times 2$ & $298(2.69)$ & $7423(2006)$ \\
\hline
\end{tabular}

chi-square: 967.457 ; p: 0.000 .

Applied rabies protocols vary depending on the attacking animal and lesion type. When patient have no visible lesion and the attacking animal is owned and vaccined, they are only monitored during hospital visits. When patient has an open wound and attacking animal is unknown, mostly $2+1+1$ vaccination protocol is applied. When patient has an open wound and attacking animal is owned, various prophylactic protocols are applied. Of all, 3238 cases $(43.6 \%)$ were treated with $2+1+1$ vaccination protocol, 528 patients (7.1\%) with $2+1+1+$ immunglobülin protocol, 2556 patients $(34.4 \%)$ with monitoring for 10 days, 955 patients $(12.9 \%)$ with 5 doses of vaccine, 146 patients $(\% 2)$ with 2 doses or 0-3-7 vaccination protocols. Vaccination protocol is performed to TC health ministry basic health services rabies prevention and control guidelines ${ }^{3}$. (Table 5)

Table 5. Applied rabies protocol.

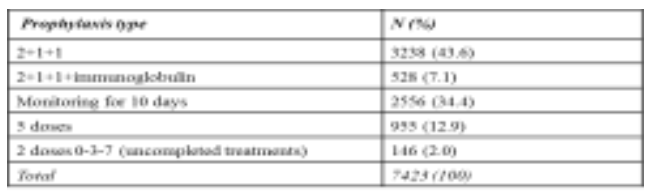

\section{DISCUSSION}

Most of the ARI victims were men (66.4\%) in our study. The same result can be seen in various studies in the literature ${ }^{4,5}$. We believe that males are more prone to ARI incidents, as they spend more time in open areas and tend to take more risks ${ }^{6}$. The average age of the victims was 31.71 . More importantly, approximately $10 \%$ of our patients was less than 10 years old. Considering that this age group is the highest risk group for rabies, both interaction and frequency can be decreased by taking necessary precautions to prevent the ARI incidents in this age group.

ARI incidents happen more often in spring and summer days ${ }^{4,7,8}$. We also found that the number of victims coming to EDs increase during summer. We believe that it is due to the fact that children and adults spend more at outdoors as it is summer holiday and spring-summer period is the breeding season for animals. A study conducted in Thailand showed that there is no seasonal changes in the number of adult victims but the number of children victims increases in school holidays ${ }^{8}$.

It has been identified that various contact types such as biting, scratching and animal saliva contact with an open wound. In our study, we found that the $80.8 \%$ of the victims are bitten by the animal. Other studies conducted in Turkey have also similar results; biting is the most common contact type $^{7,9,10}$. In our study, in almost 3 out of 4 incidents, attacking animal was a dog. Studies conducted in Turkey ${ }^{5}$ and USA $^{11}$ also reported that dogs are the attacking animal in approximately $70 \%$ of the ARI incidents. Based on this fact, laceration is the most common lesion type. Our study also found that laceration to be the most common lesion type. In contrast Gündüz et al. ${ }^{12}$ found scratches as the most common lesion type (59.3\%). Attacking animal and the contact type (biting, scratching etc.) are the determinants of lesion type and size. Considering dogs are the most common attacking animal and they have more powerful tooth and jaw structure compared to cats and other small animals it is logical that laceration is the most common lesion type found in our study.

When we examined the relation between the attacking animal and contact location, we found that extremities were much more effected. Almost $92 \%$ of the victims in our study had lesions on their upper and lower 
extremities. Contact location varies depending on the attacking animal and the age of the victim ${ }^{12}$. Other studies in the literature also reported that extremities were attacked in ARI incidents and upper extremities were more affected than lower extremities $^{13-16}$. We believe that this relation is due to the fact one usually uses his/her hands and arms to protect himself/herself in such incidents and people usually use their hands to interact with cats and dogs. We found a statistically significant relation between the contact location and attacking animal. Dogs attack consistently to lower and upper extremities. Another important result found by our study in terms of contact location is that most of the victims wounded from the head and neck are less than 10 years old $(37.2 \%)$. The number of lesions in the neck and head region was significantly high in this age group $(\mathrm{p}<0.05)$. This may be due to the fact that the head and neck area of children is proportionately much bigger and children are shorter; thus animal can easily reach these areas.

In our study, most of the victims had not taken rabies prophylaxis before. When the applied rabies protocol is examined, we saw that prophylactic protocol varies depending on the existence of lesions, ownership status of the attacking animal, vaccination status of the attacking animal and lesion type. When victim has an open wound and the owner or vaccination status of the attacking animal is unknown, mostly $2+1+1$ vaccination protocol was preferred. But when the attacking animal is known, it was held under observation for 10 days. Gündüz et all. has been reported similar prophylaxis rates in ARI cases ${ }^{12}$.

As this is a retrospective study, it is hard to determine the infections after the ARI incident. But as far as we managed to obtain the medical history of victims, we found that only in 672 victim (9.05\%), wound became infected. But no sequela development is reported in this population. This infection rate we found to be approximately $10 \%$ in our study is also reported to vary between $2-80 \%$ in the literature. It is 3$18 \%$ for dogs, $28-80 \%$ for cats and 25 for rodents ${ }^{17}$.

\section{CONCLUSION}

This retrospective study is conducted in the rabies center of a major city in Turkey and investigated a big sample. So we believe that its results will guide the future multicentered, prospective studies with larger samples. Recording and vaccination of street animals by municipalities in metropolitans like Ankara may reduce the number of ARI and measure of rabies prophylaxis. ARI incidents are a challenge for ED clinicians as it varies greatly in terms of victim profile and lesion types. So a more dynamic approach should be adapted for these patients compared to standard ED protocols.

\section{REFERENCES}

1. Weiss HB, Friedman DI, Coben $\mathrm{JH}$. Incidence of dog bite injuries treated in emergency departments. JAMA 1998; 279: 51-3.

2. Aksoy M, Demirbaş B, Maden F ve ark. Ankara İlinde 2005-2009 Yılları Arasinda Görülen Şüpheli Isırikların Ve Kuduz Aşılamasının Değerlendirilmesi. 3. Ekmud Kongresi, Ankara. Kongre Özet Kitabı 12-16 Mayis 2010:199.

3. TC Sağlık Bakanlığı Temel Hizmetleri Genel Müdürlüğü Kuduz Koruma ve Kontrol Yönergesi, 2005, Ankara

4. cdc. Rabies Virus. Available from: http//www.cdc.gov/Rabies/Virus. html. Available date: November 01, 2013.

5. Özsoy M, Yakıştıran S, Özkan E. 2000 yllinda kuduz aş1 merkezine başvuran hastalarm değerlendirilmesi. Turk Hij Den Biyol Derg 2002; 59: 1-6.

6. Foord AJ, Heine HG, Pritchard LI, Lunt RA, Newberry KM, Rootes $\mathrm{CL}$, et al. Molecular diagnosis of lyssaviruses and sequence comparison of Australian bat lyssavirus samples. Aust Vet J 2006; 84: 22530.

7. Gürçay M, Turan T, Özkaraca M, İrehan B. Türkiye'nin Doğu Ve Güneydoğu Anadolu Bölgelerinde Hayvan Kuduzunun Epidemiyolojisi. F.Ü.Sağ. Bil Vet Derg 
2010; 25: 61-6.

8. Goswami A, Plun-Favreau J, Nicoloyannis N, Sampath G, Siddiqui MN, Zinsou JA. The real cost of rabies post-exposure treatments. Vaccine 2005; 23: 2970-6.

9. Turgut S.Ş., Kemalpaşa'da Kuduz Riskli Temas Olgularmda Profilaksi Yaklaşımı Uygunluğunun Değerlendirilmesi, Dokuz Eylül Üniversitesi, İzmir 2010.

10. Ustaçelebi Ş, Kuduz Virusu, Ustaçelebi Ş, Temel Ve Klinik Mikrobiyoloji. S.981- 5. Birinci Bask1, Güneş Kitabevi, Ankara, 1999.

11. Moore DA, Sischo WM, Hunter A, Miles T. Animal bite epidemiology and surveillance for rabies postexposure prophylaxis. J Am Vet Med Assoc 2000; 217: 190-4.

12. Gündüz $T$, Elçioğlu Ö, Balcı Y. Beş ylllk süreçte köpek ve kedi ısırıklarının değerlendirilmesi: Eskişehir'den örnek bir çalışma. Ulus Travma Acil Cerrahi Derg 2011; 17: 133-40.

13. Ostanello F, Gherardi A, Caprioli A, La Placa L, Passini A, Prosperi S. Incidence of injuries caused by dogs and cats treated in emergency departments in a major Italian city. Emerg Med J 2005; 22: 260-2.

14. Patrick GR, O'Rourke KM. Dog and cat bites: epidemiologic analyses suggest different prevention strategies. Public Health Rep 1998; 113: 252-7.

15. Shetty RA, Chaturvedi S, Singh Z. Profile of animal bite cases in $\mathrm{Pu}$ ne. J Commun Dis 2005; 37: 6672.

16. Lang ME, Klassen T. Dog bites in Canadian children: a five-year review of severity and emergency department management. CJEM 2005; 7: 309-14.

17. Bregman B, Slavinski S. Using emergency department data to conduct dog and animal bite surveillance in New York City, 20032006. Public Health Rep 2012; 127: 195-201. 